\title{
Ventral abdominal wall defect correction in rats with contaminated meshes ${ }^{1}$
}

\author{
Paola Zarur Varella', Nicolau Gregori Czeczko", Manoel Alberto Prestes ${ }^{\mathrm{III}}$, Alexandre Eduardo Augustin Czeczko ${ }^{\mathrm{IV}}$, Marília da \\ Cruz Fagundesv, Roberta Dombroski Petiscov
}

DOI: http://dx.doi.org/10.1590/S0102-865020160100000007

IFellow Master degree, Postgraduate Program in Principles of Surgery, Medical Research Institute, Faculdade Evangélica do Paraná (FEPAR), CuritibaPR, Brazil. Technical procedures, design of the study, manuscript preparation.

IIPhD, Associate Professor, Department of Surgery, FEPAR, Curitiba-PR, Brazil. Design of the study, critical revision, final approval of the manuscript. IIIPhD, Assistant Professor, Department of Surgery, FEPAR, Curitiba-PR, Brazil. Design of the study, critical revision, final approval the manuscript.

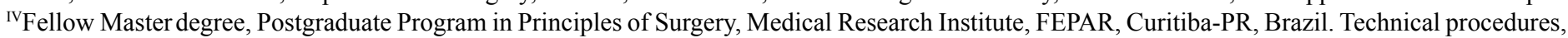
acquisition of data, manuscript preparation.

${ }^{v}$ Graduate student, School of Medicine, PIBIC, FEPAR, Curitiba-PR, Brazil. Technical procedures, acquisition of data.

\begin{abstract}
PURPOSE: To investigate whether there is a difference between Marlex ${ }^{\circledR}$ and Dynamesh PP-light Marlex ${ }^{\circledR}$ meshes, in the abdominal wall defect correction, on rats in contaminated surgical site.

METHODS: Twenty-eight Wistar rats were divided into two groups of 14, and four subgroups of seven animals. All subgroups underwent similar surgical procedure. One group received the mesh Marlex ${ }^{\circledR}$ and the other Dynamesh PP-light ${ }^{\circledR}$ for correction of the defect. Before implanting, the meshes went through a contamination process, on which was used standard solution containing 10 UFC of Escherichia coli. Fragments of the animal's abdominal wall received macroscopic, microscopic and microbiological analysis.

RESULTS: There was no statistical significance in the analysis of macroscopic variables. Accentuated inflammatory process was shown in all subgroups. The foreign body type reaction was mild in all subgroups, except Dynamesh ${ }^{\circledR}$ - 14 , which was moderate with no statistical significance. The microbiological analysis of the meshes was also similar between the subgroups.

CONCLUSION: There was no difference between the meshes of Marlex ${ }^{\circledR}$ and Dynamesh PP-light ${ }^{\circledR}$ in the ventral abdominal wall defect correction on rats in contaminated surgical site.
\end{abstract}

Key words: Incisional Hernia. Surgical Mesh. Materials Testing. Rats. 


\section{Introduction}

The incisional hernias or abdominal wall eventrations are frequent complications of abdominal surgery by laparotomy, estimating its incidence in 2-8\%. Among the main risk factors for its appearance, are wound infection and obesity, among others ${ }^{1-3}$.

The surgical treatment is usually laborious and has high recurrence rates, even with experienced hands. There are several techniques for repair, from aponeurotic flaps to tension-free techniques, using synthetic prosthesis ${ }^{4}$.

The development of polypropylene prosthesis revolutionized surgery for repair of the abdominal wall hernia. When compared to basic repairs, the tension-free techniques reduced recurrences and made possible the reconstruction of large ventral defects that were irreparable ${ }^{5}$.

Despite initial concerns about the possible rejection and infection, resulting from the use of prosthesis, there is evidence that tension-free hernioplasties using biomaterials, have significantly reduced recurrence and complication rates, making it accepted worldwide ${ }^{6}$.

The quality of synthetic meshes and surgical techniques has shown great developments in the past years. Materials such as polypropylene, polyglactin, polytetrafluoroethylene, woven polyester, polyvinylidene, among others, may be part, alone or in combination, of the composition of meshes currently used ${ }^{7-12}$. Besides the material, which forms the mesh, its density also gives it particular characteristics. High density or microporous meshes (pores smaller than $10 \mu \mathrm{m}$ ) may increase the chance of infection and fistula formation ${ }^{13,14}$. However, the low density or macroporous meshes (pores larger than $75 \mu \mathrm{m}$ ) prevents the development of infections ${ }^{15,16}$.

Often times the surgeon finds strangulated ventral hernias, urgently operated, with occlusion or with associated intestinal sub-occlusion, which favors the phenomenon of bacterial translocation. Considering several other clinical situations of possible peritoneal cavity contamination, such as those that occur directly through intestinal necrosis with perforations, fistulas and bacterial peritonitis, or in patients who underwent elective abdominal surgery with opening of the gastrointestinal tract and require associated herniorrhaphy, there is always the question as to whether or not use prosthesis, and what is the most appropriate prosthesis for this situation.

Thereby, this study aims to determine if there is a difference between the meshes of Marlex ${ }^{\circledR}$ and Dynamesh PPlight ${ }^{\circledR}$ in the ventral abdominal wall defect correction on rats in contaminated surgical site.

\section{Methods}

This study took place at the Experimental Surgery Laboratory of the Faculdade Evangélica do Paraná, after approval by the Ethics Committee on Animal Research.

The sample consisted of 28 Wistar rats (Rattus novergicus albinus) males, adults, weighing between 280-358g, and the groups identified by picric acid staining at certain points, keeping the rats on day and night cycles of $12 \mathrm{~h}$ at room temperature of $24^{\circ} \mathrm{C}$. Throughout the experiment, they received proper feed for the species and had free access to water.

For the experiment were used meshes of Marlex ${ }^{\circledR}$ and DynaMesh - PP light ${ }^{\circledR}$ (Figure 1).

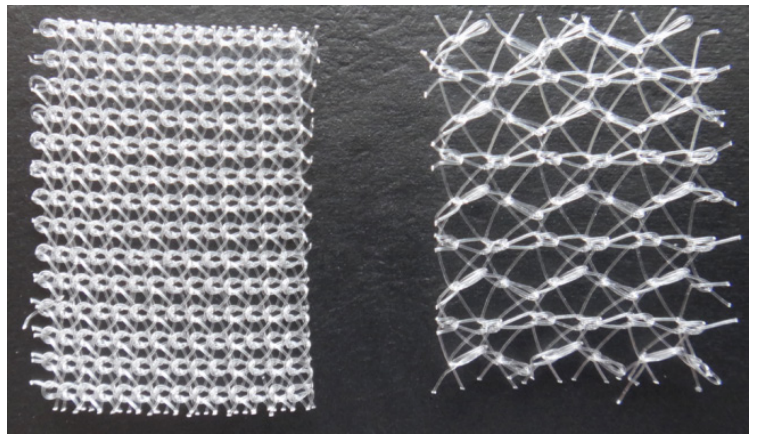

FIGURE 1 - To the left, meshes of Marlex ${ }^{\circledR}$ and to the right, Dynamesh PP-light ${ }^{\mathbb{R}}$

The mesh of Marlex $^{\circledR}$ consists of polypropylene monofilament classified as microporous (pores of $0.6 \mathrm{~mm}$ ) and heavy grammage $\left(95 \mathrm{~g} / \mathrm{m}^{2}\right)$. As Amid $\mathrm{P}^{17}$ defined meshes with larger pores than 75 microns are considered macroporous. These can be considered large pores when the pores are larger than $1.5 \mathrm{~mm}$ or 150 microns. Then the meshes used in the study are macroporous with large pores (DynaMesh PP light) and small pores (Marlex). The DynaMesh-PP light ${ }^{\circledR}$ is composed of polypropylene monofilament, classified as macroporous (pores of $2.6 \mathrm{~mm})$ and low grammage $\left(36 \mathrm{~g} / \mathrm{m}^{2}\right)$. The meshes were cutted into pieces of $2.0 \times 2.5 \mathrm{~cm}$, and contaminated with standard solution of Escherichia coli. The strains were cultivated in BHI broth; batch YF209, sterile, at $36^{\circ} \mathrm{C}$. The solution was prepared $24 \mathrm{~h}$ before the experiment and reached a final concentration of $10^{\mathrm{a}} \mathrm{UFC}$.

The 28 animals were split randomly into two groups of 14. The groups were given names related to the used meshes. The Marlex ${ }^{\circledR}$ group was subdivided in two subgroups of seven animals. In the Marlex ${ }^{\circledR}-7$ subgroup, the euthanasia occurred on the $7^{\text {th }}$ day after surgery and in the Marlex ${ }^{\circledR}-14$ subgroup, the euthanasia on the $14^{\text {th }}$ day. The Dynamesh ${ }^{\circledR}$ group was divided into two groups 
of seven. In the Dynamesh ${ }^{\circledR}-7$ subgroup, the euthanasia occurred on the $7^{\text {th }}$ postoperative day and in the Dynamesh ${ }^{\circledR}-14$ subgroup, on the $14^{\text {th }}$ day.

A digital scale weighed the animals and then forwarded them to the anesthesia. Each rat received a mixture of ketamine (90 $\mathrm{mg} / \mathrm{kg})$ and xylazine $(10 \mathrm{mg} / \mathrm{kg})$ intraperitoneally. The animals received anesthesia and considered ready for the surgical procedure as soon as they lost ocular and caudal reflexes.

The surgical procedures began with sub-xiphoid midline incision of approximately $3 \mathrm{~cm}$ length, followed by muscleaponeurotic resection of $1.0 \times 1.5 \mathrm{~cm}$ on the upper left quadrant of the abdominal wall without opening of the peritoneum (Figure 2).
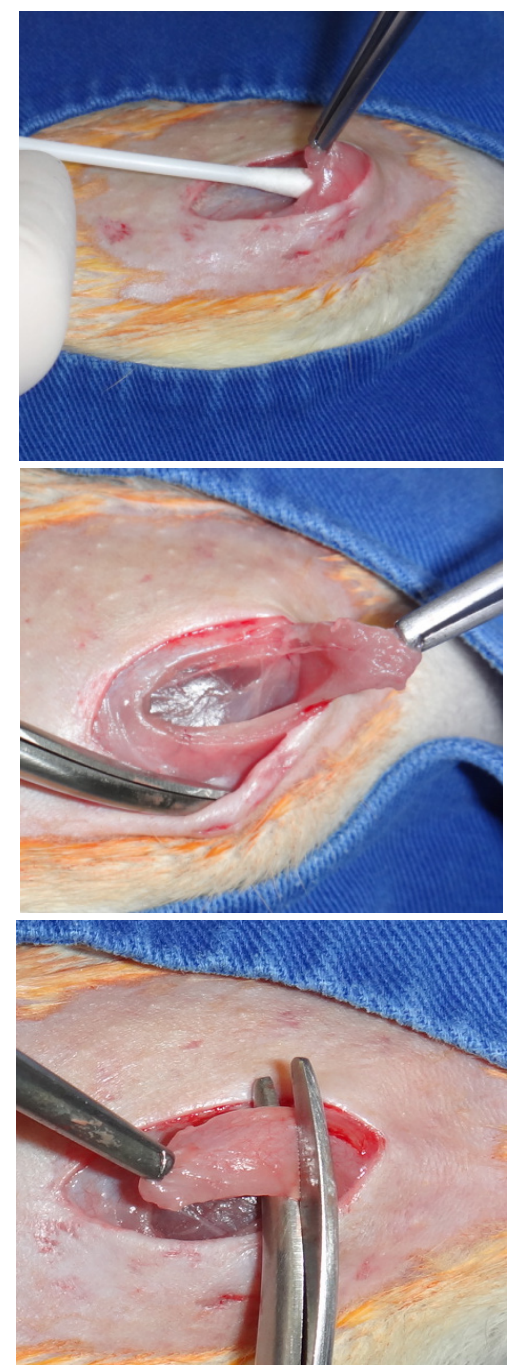

FIGURE 2 - Muscle-aponeurotic resection in the upper left quadrant.

Cutted meshes were submerged in the standard solution of Escherichia coli, stored in a Becker and applied in the muscular plane, with four separate points of polypropylene 4-0 (Figure $3)$. Then, the skin was closed with continuous suture, using polypropylene thread 4-0.

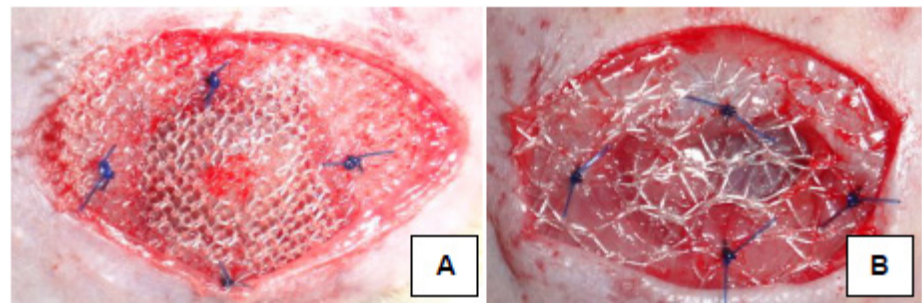

FIGURE 3 - Meshes fixed in the muscular plane: A) Marlex $^{\circledR}$ and B) Dynamesh PP-light ${ }^{\circledR}$.

The animals were kept warm, until complete recovery from anesthesia, with free access to water and food. The sedation in postoperative occurred with the subcutaneous administration of tramadol $(15 \mathrm{mg} / \mathrm{kg})$, in daily doses during the first three days. Daily evaluation was done by checking the disposition, dietary compliance, motor activity and possible complications with the surgical wound.

The euthanasia occurred on programmed days and carried out through poisoning by carbon dioxide in a closed chamber.

Immediately after euthanasia, was evaluated the surgical wound for the presence or absence of hematoma, seroma, skin necrosis or wound dehiscence. Next, was performed antisepsis of the abdominal wall with topical PVPI. The instruments used were sterile. Then, was made an incision in "C", from the upper left quadrant to the left iliac fossa, folding up the skin and subcutaneous tissue of the ventral wall, widely exposing the surgical site. Next, evaluation for the presence of collections, signs of infection and intra-abdominal adhesions was done (Figure 4).

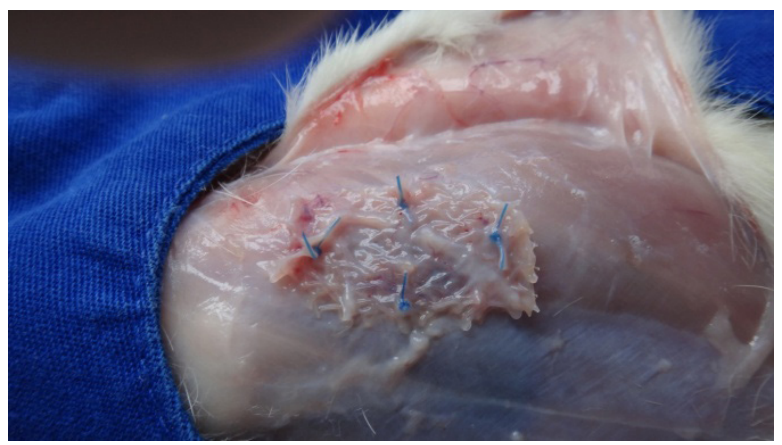

FIGURE 4 - Incision in "C" exposing the surgical site.

To quantify the macroscopic analysis, was used the graduation $0=$ absent, $1=$ present, in the following items: skin necrosis; dehiscence in the surgical wound; seroma; hematoma at the surgical site; infection at the surgical site; and intra-abdominal adhesions.

Resection of a specimen, involving the complete operative area, was realized in all and with a cross section, they were divided into two equal parts. The cranial half was stored in 
sterile bottle with saline solution of $0.9 \%$ and sent for culture; the caudal, fixed in a cardboard template avoiding retraction into the bottle of formaldehyde (10\% formalin) and sent for microscopic analysis. All vials received proper identification.

For microscopic analysis, the slides were processed in the usual way and stained with hematoxylin-eosin. In analysis, the slides were evaluated as following: acute inflammatory process or polymorphonuclear, and chronic or monomorfonuclear, and foreign body reaction or gigantocellular.

The cell count occurred by means of blind evaluation, where the pathologist had no knowledge of which subgroup he was evaluating. Based on the average of cells in the five largest power fields, ranked inflammation and gigantocellular in mild, moderate or marked on each animal (Figure 5).

\begin{tabular}{cc}
\hline $\begin{array}{c}\text { Intensity of the } \\
\text { inflammatory process }\end{array}$ & Average of cells/field 400x \\
\hline Mild & Up to 5 neutrophils or lymphocytes \\
Moderate & $6-20$ neutrophils or lymphocytes \\
Marked & $>20$ neutrophils or lymphocytes \\
\hline Intensity of & Average of cells/field 400x \\
gigantocellular reaction & \\
\hline Mild & Up to 3 giant cells \\
Moderate & $4-7$ giant cells \\
Marked & $>7$ giant cells \\
\hline
\end{tabular}

FIGURE 5 - Classification of the inflammatory and gigantocellular processes.

For microbiological analysis of the surgical specimen, was held culture in blood and MacConkey agar and considering positive if there was growth of Escherichia coli at any concentration after $48 \mathrm{~h}$ in culture medium.

\section{Statistical analysis}

The results of quantitative variables were described by medians, minimum and maximum values, and the qualitative as frequencies and percentages. For comparing two groups in relation to qualitative variables considered the Fisher exact test and for the quantitative, non-parametric Mann-Whitney. Values of $\mathrm{p}<0.05$ showed statistically significance. Analyzed the data with the computer program IBM SPSS Statistics v.20.

\section{Results}

The surgical procedures passed appropriately. The surgical average time was 10 min for each animal. There was an accidental opening of the parietal peritoneum in one animal from the Marlex ${ }^{\circledR}-7$ subgroup. In this animal, it was opted to perform the procedure in the upper right quadrant.

The animals had good postoperative evolution. One of the Marlex ${ }^{\circledR}-7$ subgroup died in the immediate postoperative period.

\section{Macroscopic analysis}

The Figure 6 illustrates the macroscopic appearance of the normal evolution of the healing process in the Marlex ${ }^{\circledR}-14$ and Dynamesh ${ }^{\circledR}-14$ subgroups.

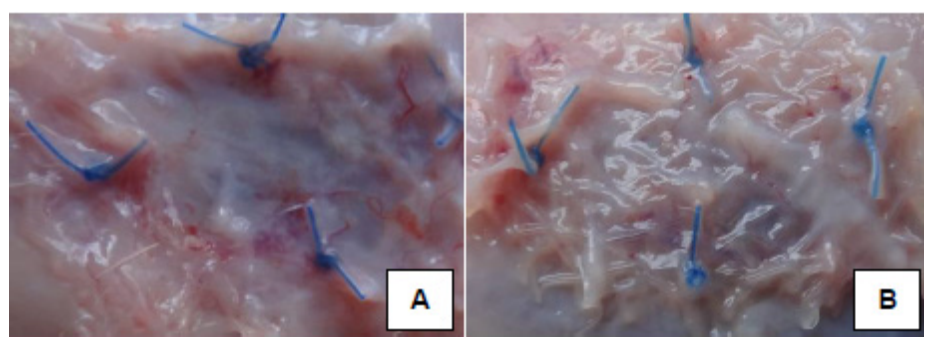

FIGURE 6 - Normal evolution of the healing process: A) Marlex ${ }^{\circledR}-14$; B) 14-Dynamesh ${ }^{\circledR}$.

\section{Necrosis}

One animal of the Marlex ${ }^{\circledR}-7$ subgroup evolved with necrosis of the entire surgical wound extension, beyond an underlying abscess. One animal of the Dynamesh ${ }^{\circledR}-7$ subgroup showed a necrotic spot in the pelvic region, associated with an intra-cavity abscess in this topography. There was no statistical significance in subsection necrosis in both groups (Figure 7).

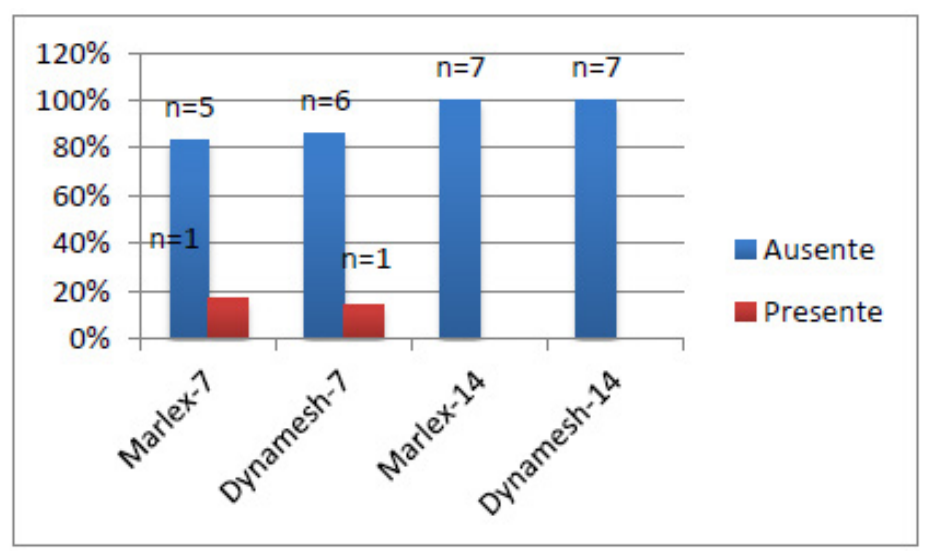

FIGURE 7 - Details of necrosis in the subgroups $(\mathrm{p}=1)$. 


\section{Dehiscence of surgical wound}

One animal from the Dynamesh ${ }^{\circledR}-14$ subgroup evolved with partial dehiscence with wound associated to the abscess at the surgical site. There was no statistical significance in the subsection wound dehiscence (Figure 8).

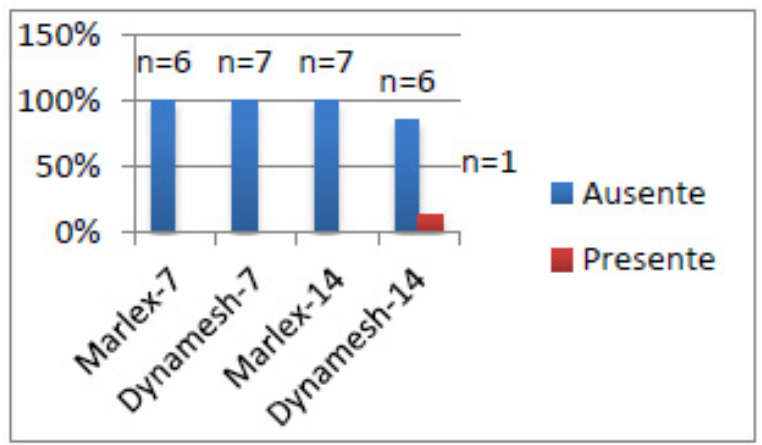

FIGURE 8 - Dehiscence of surgical wound in the subgroups $(\mathrm{p}=1)$.

\section{Seroma}

Two animals from the Marlex ${ }^{\circledR}-7$ subgroup presented seroma at the implantation site of the surgical mesh. There was no statistical significance in the subsection seroma in both subgroups (Figure 9).

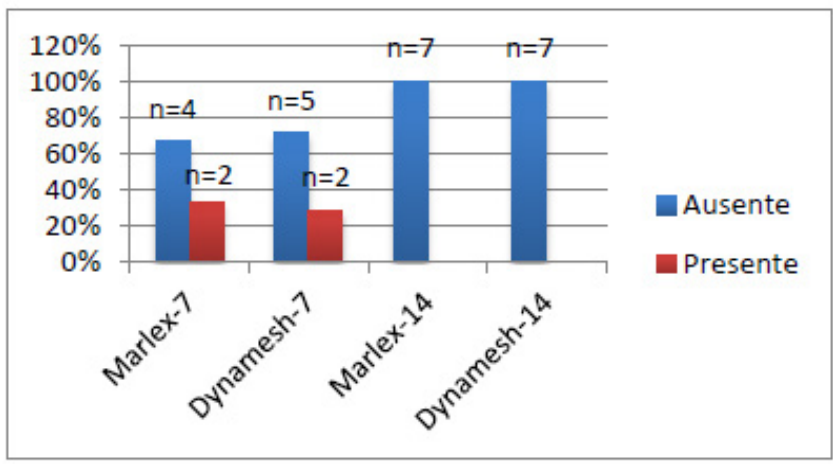

FIGURE 9 - Seroma in the subgroups $(\mathrm{p}=1)$.

\section{Hematoma at the surgical site}

No animal showed hematoma.

\section{Surgical site infection}

Abscess in the abdominal wall was present in one animal from the Marlex ${ }^{\circledR} 7$-subgroup and one from the Marlex ${ }^{\circledR}-14$ subgroup (Figure 10). One animal from the Dynamesh ${ }^{\circledR}-7$ subgroup showed an intra-cavity abscess in the pelvic area and one from the Dynamesh-14 subgroup presented an abscess in the abdominal wall.

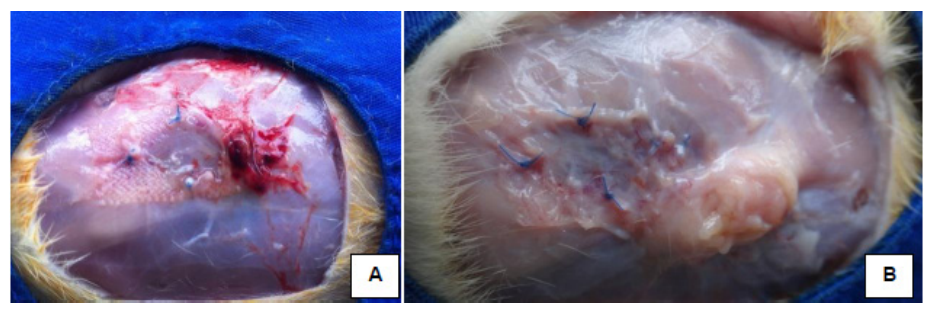

FIGURE 10 - Presence of abdominal wall abscess on animals from the Marlex ${ }^{\circledR}$ subgroup-14 (A) and Dynamesh-14 ${ }^{\circledR}($ B).

There was no statistical significance in the subsection surgical site infection in both subgroups (Figure 11).

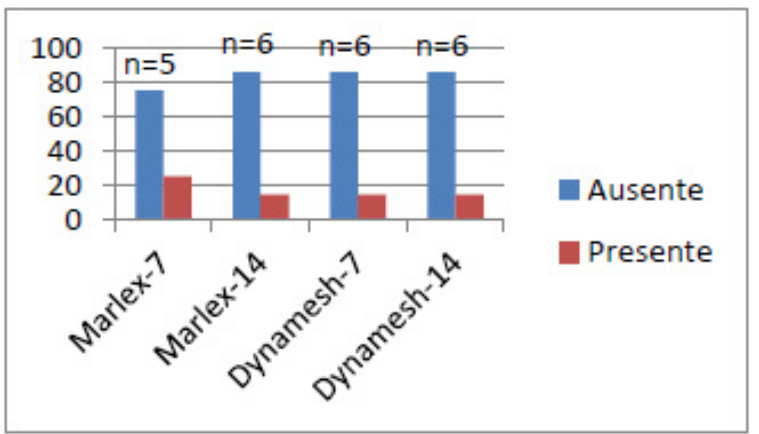

FIGURE 11 - Infection in the subgroups $(\mathrm{p}=1)$.

\section{Intraperitoneal adhesions}

No animal showed intraperitoneal adhesions.

\section{Microscopic analysis}

In the Marlex $^{\circledR}$ 7-subgroup, the average polymorphonuclear cells was 50.83 and the median 31.8 . The average mononuclear cells was 40.09 and median of 39.1. The average foreign body giant cells was 3.23 with a median of 2.6. It characterized as inflammation of sharp intensity, with mild foreign body reaction (Figure 12A).

In the Dynamesh ${ }^{\circledR}-7$ subgroup, the average of polymorphonuclear cells was 40.85 with a median of 32.8 . The average of mononuclear cells was 53.82 with a median of 53.4. The average of foreign body giant cells was 1.54 , with a median of 1.8. Characterized as severe inflammation and mild foreign body 
reaction (Figure 12B). The analysis of inflammatory cells showed no statistical difference between the subgroups of seven days.
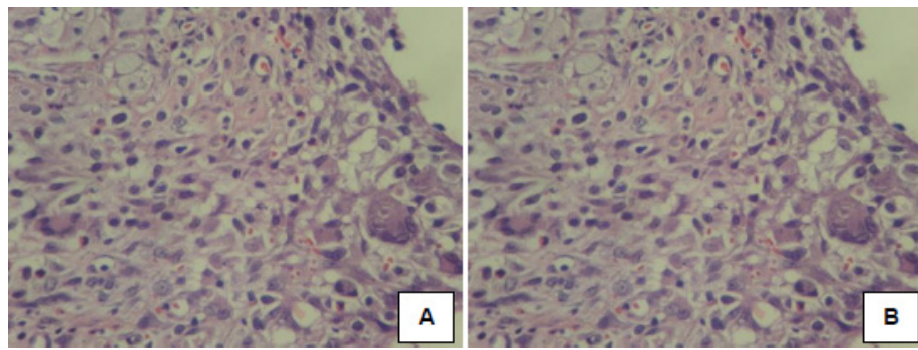

FIGURE 12 - Severe inflammatory process in the subgroups Marlex $^{\circledR}-7$ (A) and Dynamesh ${ }^{\circledR}-7(\mathbf{B})$.

In the Marlex $^{\circledR}$ subgroup-14, the average polymorphonuclear cells was 24.48 and the median 24.6. The average mononuclear cells was 53.74 and the median 59. The average of foreign body giant cells was 3.17 with a median of 3.0. Characterized as severe inflammatory process with mild foreign body reaction (Figure 13A).

In the Dynamesh-14 subgroup, the average polymorphonuclear cells was 20.88 and the median 21.8 cells. The average of mononuclear cells was 56.02 and the median was 53.4 cells. The average of foreign body giant cells was 4.37 with a median of 3.0 characterized as marked inflammation with moderate foreign body reaction (Figure 13B). The analysis of inflammatory cells showed no statistical difference between the subgroups.
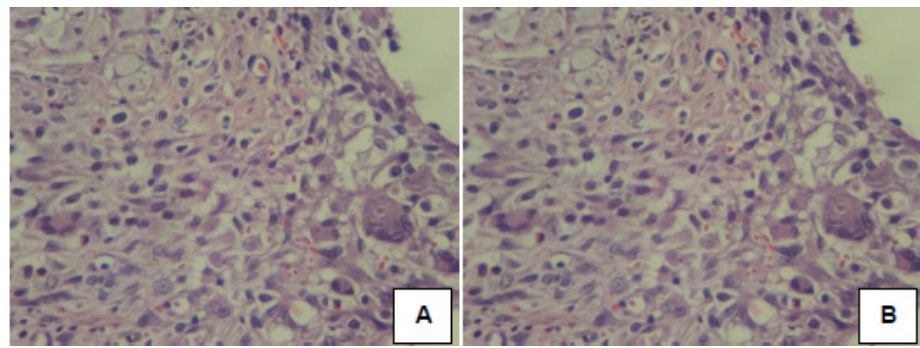

FIGURE 13 - Severe inflammatory process in the subgroup Marlex ${ }^{\circledR}-14$ (A) and Dynamesh ${ }^{\circledR}-14$ (B).

Comparing the Marlex ${ }^{\circledR}-7$ and Marlex ${ }^{\circledR}-14$ subgroups, it was noticed that the number of polymorphonuclear leukocytes and giant cells decreased while the mononuclear increased, featuring chronicity of the process (Figure 14A).

The same cell behavior appeared when comparing the Dynamesh $^{\circledR}-7$ subgroups Dynamesh $^{\circledR}-14$ (Figure 14B).

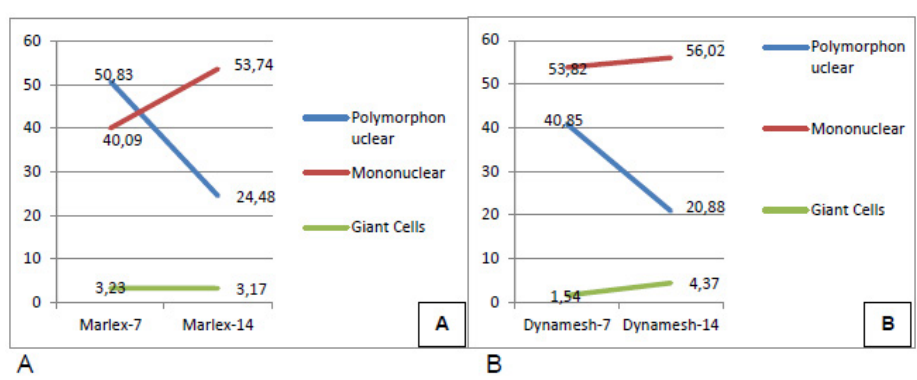

FIGURE 14 - Evolutionary cellularity in the subgroups Marlex $^{\circledR}-7$ and Marlex $^{\circledR}-14$ (A) and Dynamesh ${ }^{\circledR}-7$ with Dynamesh ${ }^{\circledR}-14(\mathbf{B})$.

\section{Microbiological analysis}

Three animals from the Marlex ${ }^{\circledR} 7$-subgroup and three from the Dynamesh ${ }^{\circledR}-7$ subgroup presented positive cultures for Escherichia coli. There was no statistical difference between the subgroups. Three animals from the Marlex ${ }^{\circledR}-14$ subgroup and two from the Dynamesh ${ }^{\circledR}-14$ subgroup presented positive cultures for Escherichia coli. There was no statistical difference between the subgroups.

\section{Discussion}

The chosen animal for the research is the rat, due to its widely usage in studies involving meshes and repair of abdominal wall defects ${ }^{8,17,18}$.

There is no consensus in literature on the ideal prosthesis for use in contaminated environment. In most situations, one should choose low-density meshes with large pores and minimal surface area. Ideally, it should consist of a monofilament. If the mesh is placed in the peritoneal cavity, it needs a hybrid with a mesh of absorbable surfaces ${ }^{6,19,20}$.

The development of the polypropylene prosthetic revolutionized surgery for abdominal wall defects correction. The reduction in density of polypropylene, with the creation of lightweight meshes, theoretically reduced the foreign body reaction, causing less mesh contraction and providing better mesh incorporation in the abdominal wall, resulting in improved physiology of the abdominal wall ${ }^{21-23}$. Utiyama et al. ${ }^{24}$ already showed no difference between polypropylene (high-density) and Ultrapro(r) (low-density) meshes at 21 days after surgery in extraperitoneal use in rats, comparing inflammatory response, mesh shortening, adhesions or complications.

This research focuses on experimental study of contaminated meshes in abdominal wall defect correction. This 
scenario simulates emergencies with incarcerated and strangulated hernias, in addition to elective situations where it is required to open the gastrointestinal tract, such as the paracolostomy hernia repair. The mesh used in the study was the polypropylene, chosen by being the most widespread and used both globally and in our field ${ }^{25}$.

The Escherichia coli is the most widely used bacteria in experimental studies that worked with contamination. Most studies use standard solutions containing this microorganism ${ }^{25-27}$. In 1989, Deitch et al. ${ }^{28}$ in a clinical study of patients operated in emergency situations, with or without intestinal occlusion, noted that $59 \%$ had bacterial translocation and the more involved bacteria was Escherichia coli.

The option to use Escherichia coli for research, found that in cases of intestinal obstruction in strangulated hernias, the possibility of bacterial translocation can occur and this is the bacteria most often involved in these cases ${ }^{28,29}$ and also is in the incidental openings of the human gastrointestinal tract.

The average time of the surgical procedure was approximately $10 \mathrm{~min}$ per animal. The most delicate moment of the surgery was the blunt dissection of the abdominal wall muscles, so that there was no violation of the parietal peritoneum, since the used meshes could not get in contact with the intra-abdominal viscera. Performing this blunt dissection with the aid of a swab was performed without difficulties.

\section{Macroscopic evaluation}

Barbuto et $a l .{ }^{30}$ studied the polypropylene meshes behavior in rats with and without induced peritonitis. It identified $50 \%$ of wound dehiscence in rats with peritonitis and $60 \%$ of those without peritonitis, with no statistical difference. This study observed incidence of $14.3 \%$ of wound dehiscence, which occurred in the Dynamesh ${ }^{\circledR}-14$ subgroup, a result similar to the study of found $12.5 \%$ of dehiscence of the surgical wound in Ultrapro-7 subgroup and $12.5 \%$ of wound dehiscence in the Proceed-28 subgroup.

The occurrence of seroma in the surgical site was early complication, as was present in $33.4 \%$ of the animals of the Marlex $^{\circledR}-7$ subgroup, $28.6 \%$ of Dynamesh ${ }^{\circledR}-7$ and no animal of the 14 days subgroups. Our incidence of seroma was similar to that found by Klinge et al. $.^{22}, 36 \%$ in the heavyweight meshes group and $20 \%$ in the lightweight. Greca et al. ${ }^{21}$ in study comparing meshes of heavyweight and lightweight, in dogs, observed a rate of $20 \%$ of seroma in both meshes.
Was not found the formation of hematomas in any animal, as well as Utrabo et $a l .{ }^{32}$. Pundek et al. ${ }^{31}$ had $12.5 \%$ incidence of hematoma in the Proceed-15 subgroup. Isa et al. ${ }^{3}$ found $11 \%$ of hematoma in the Ultrapro-7 subgroup and $12.5 \%$ in the Proceed-7 subgroup.

Exactly one animal from each of the four subgroups of this study developed an abscess at the surgical site. Pundek et al. ${ }^{31}$ and Utrabo et al $^{32}$ did not show any cases of surgical site infection, as their paper did not involve any source of contamination of the surgical site. In disagreement with literature - since the rat is very resistant to infections - Isa et al. ${ }^{3}$ showed high rates of early infection at the surgical site; the first author, with $55.6 \%$ of infection and the second, with $66.7 \%$ in the subgroups of seven days.

No animals in this study presented intra-peritoneal adhesions. We only compared this result with Utrabo et al. ${ }^{32}$ because it was the only one to preserve the peritoneum, not allowing the prosthesis to come into direct contact with the intraabdominal viscera. The author found $18.75 \%$ of adhesions in the 30 days subgroup and $6.25 \%$ in 60 days, with no statistical significance.

\section{Microscopic evaluation}

In this study, was found no statistically significant difference in the evaluation of inflammatory response among Marlex $^{\circledR}-7$ subgroups and Dynamesh ${ }^{\circledR}-7$, or between Marlex ${ }^{\circledR}-14$ and Dynamesh ${ }^{\circledR}-14^{21}$.

Other studies with polypropylene meshes concluded that the higher the mesh grammage, greater the inflammatory response and surgical complications, determining a better biocompatibility of lightweight meshes ${ }^{13,22,23}$.

In disagreement, Weyhe et al. ${ }^{19}$ in an experimental study in rats found worst biocompatibility of low-density meshes in comparison with high-density.

\section{Microbiological evaluation}

This study found positive cultures in $50 \%$ of the animals of the Marlex ${ }^{\circledR}-7$ subgroup and $42.9 \%$ of the Dynamesh ${ }^{\circledR}-7$ subgroup. In Marlex ${ }^{\circledR}-14$ subgroup, the positive cultures was $42.9 \%$, and Dynamesh ${ }^{\circledR}-14,28.6 \%$. However, at different times, Sebben et al. ${ }^{25}$ obtained positive meshes cultures of $83 \%$ when the reoperation was in $24 \mathrm{~h}, 33 \%$ when in $48 \mathrm{~h}$ and $17 \%$ in $72 \mathrm{~h}$. As an overall result, his group showed $44 \%$ of positive meshes cultures. 


\section{Conclusion}

There was no difference between the meshes of Marlex ${ }^{\circledR}$ and Dynamesh PP-light ${ }^{\mathbb{R}}$ in the ventral abdominal wall defect correction on rats with contaminated meshes with standard solution of Escherichia coli.

\section{References}

1. Rohr S, Vix J, Kanor M, Meyer C. Treatment of a massive incisional abdominal wall hernia requiring subtotal colectomy using a dual facing mesh. Hernia. 2000;4(Supl.1):22-4.

2. Palermo M, Acquafresca PA, Bruno M, Tarsitano F. Hernioplasty with and without mesh: analysis of the immediate complications in a randomized controlled clinical trial. Arq Bras Cir Dig. 2015 JulSep;28(3):157-60. doi: 10.1590/S0102-67202015000300002.

3. Isa AC, Matias JE, Yamamoto CT, Isa RH2, Campos AC, Coelho JC. Use of surgical mesh of different compositions in the correction of the abdominal wall defect in rats. Rev Col Bras Cir. 2015 SepOct;42(5):329-35. doi: 10.1590/0100-69912015005011.

4. Anthony T, Bergen PC, Kim LT, Henderson M, Fahey T, Rege $\mathrm{RV}$, Turnage RH. Factors affecting recurrence following incisional herniorrhaphy. World J Surg. 2000 Jan;24(1):95-100;discussion 101. PMID: 10594211.

5. Cobb WS, Kercher KW, Heniford BT. The argument for lightweight polypropylene mesh in hernia repair. Surg Innov. 2005 Mar;12(1):639. PMID: 15846448.

6. Brown CN, Finch JG. Which mesh for hernia repair? Ann R Coll Surg Engl. 2010 May;92(4):272-8. doi: 10.1308/003588410X12664 192076296.

7. Butler CE, Prieto VG. Reduction of adhesions with composite AlloDerm/polypropylene mesh implants for abdominal wall reconstruction. Plast Reconstr Surg. 2004 Aug;114(2):464-73. PMID: 15277815.

8. Burger JW, Halm JA, Wijsmuller AR, ten Raa S, Jeekel J. Evaluation of new prosthetic meshes for ventral hernia repair. Surg Endosc. 2006 Aug;20(8):1320-5. PMID: 16865616.

9. Yasojima EY, Teixeira RK, Houat Ade P, Costa FL, Yamaki VN, Feitosa-Junior DJ, Silva CA, Brito MV. Copaiba oil influences ventral hernia repair with Vicryl ${ }^{\circledR}$ mesh? Arq Bras Cir Dig. 2015 Jul-Sep;28(3):186-9. doi: 10.1590/S0102-67202015000300010.

10. Barbuto RC, Duval-Araujo I, Barral SM, Rocha RG, Bechara Cde S, Barbosa AJ. Use of alloplastic meshes in abdominal wounds of rats with induced peritonitis. Arq Bras Cir Dig. 2014 Jan-Mar;27(1):26-9. PMID: 24676294

11. Barbuto RC, Araujo ID, Bonomi DO, Tafuri LS, Calvão Neto A, Malinowski R, Bardin VS, Leite MD, Duarte IG. Use of the amniotic membrane to cover the peritoneal cavity in the reconstruction of the abdominal wall with polypropylene mesh in rats. Rev Col Bras Cir. 2015 Jan-Feb;42(1):49-55. doi: 10.1590/0100-69912015001010.

12. Utiyama EM, Pflug AR, Damous SH, Rodrigues-Jr AC, Montero EF, Birolini CA. Temporary abdominal closure with zipper-mesh device for management of intra-abdominal sepsis. Rev Col Bras Cir. 2015 Jan-Feb;42(1):18-24. doi: 10.1590/0100-69912015001005.

13. Klosterhalfen B, Klinge U, Schumpelick V. Functional and morphological evaluation of different polypropylene-mesh modifications for abdominal wall repair. Biomaterials. 1998 Dec;19(24):2235-46. PMID: 9884036.

14. Araújo URMF, Czeczko NG, Deallarmi A, Hemoviski FE, Araújo HVCP. Escolha do material da tela para disposição intra-peritoneal na correção cirúrgica de defeitos herniários da parede abdominal. ABCD. 2010;23(2):94-9. doi: 10.1590/S0102-67202010000200012.

15. Amid PK, Shulman AG, Lichtenstein IL, Hakakha M. Biomaterials for abdominal wall hernia surgery and principles of their applications. Langenbecks Arch Chir. 1994;379(3):168-71. PMID: 8052058.

16. Junge K, Klinge U, Rosch R, Klosterhalfen B, Schumpelick V. Functional and morphologic properties of a modified mesh for inguinal hernia repair. World J Surg. 2002 Dec;26(12):1472-80. PMID: 12297937.

17. Amid PK. Classification of biomaterials and their related complications in abdominal wall hernia surgery. Hernia. 1997;1(1):15-21. doi: 10.1007/BF02426382.

18. Fagundes DJ, Taha MO. Modelo animal de doença: critérios de escolha e espécies de animais de uso corrente. Acta Cir Bras. 2004;19(1):59-65. doi: 10.1590/S0102-86502004000100010.

19. Weyhe D, Schmitz I, Belyaev O, Grabs R, Müller KM, Uhl W, Zumtobel V. Experimental comparison of monofile light and heavy polypropylene meshes: less weight does not mean less biological response. World J Surg. 2006 Aug;30(8):1586-91. PMID: 16855805.

20. Novitsky YW, Harrell AG, Hope WW, Kercher KW, Heniford BT. Meshes in hernia repair. Surg Technol Int. 2007;16:123-7. PMID: 17429779 .

21. Greca FH, de Paula JB, Biondo-Simões ML, da Costa FD, da Silva AP, Time S, Mansur A. The influence of differing pore sizes on the biocompatibility of two polypropylene meshes in the repair of abdominal defects. Experimental study in dogs. Hernia. 2001 Jun;5(2):59-64. PMID: 11505649.

22. Klinge U, Klosterhalfen B, Birkenhauer V, Junge K, Conze J, Schumpelick V. Impact of polymer pore size on the interface scar formation in a rat model. J Surg Res. 2002 Apr;103(2):208-14. PMID: 11922736.

23. Zogbi L1, Trindade EN, Trindade MR. Comparative study of shrinkage, inflammatory response and fibroplasia in heavyweight and lightweight meshes. Hernia. 2013 Dec;17(6):765-72. doi: 10.1007/s10029-013-1046-2.

24. Utiyama EM, Rosa MB, Andres Mde P, Miranda JS, Damous SH, Birolini CA, Damous LL, Montero EF. Polypropylene and polypropylene/polyglecaprone (Ultrapro $\AA$ ) meshes in the repair of incisional hernia in rats. Acta Cir Bras. 2015 Jun;30(6):376-81. doi: 10.1590/S0102-865020150060000001.

25. Sebben GA, Rocha SL, Von Bahten LC, Biondo-Simões Mde L, Ramos FH, Pilonetto M, Zonatto LM. Infection on polypropylene mesh implantation site in the abdominal wall of rats with induced bacterial peritonitis. Acta Cir Bras. 2006 May-Jun;21(3):155-60. PMID: 16751929.

26. Celdran Uriarte A, Iñarrea Lasheras P, Marijuan Martin JL, Castilla Reparaz C, Ponte Miramonte MC, Madero Jarabo R, De-Oya Otero $\mathrm{M}$. Effect of povidone iodine and chlorhexidine on the mortality and bacterial clearance in the abdominal cavity of peritonitis rats. Eur J Surg. 1991 Jun-Jul;157(6-7):393-5. PMID: 1681916.

27. Waitzberg DL, Oku SMM, Soares SRC, Zanella RC, Brandileone MCC, Lima-Gonçalves E. Padronização de um modelo de peritonite em ratos. Acta Cir. Bras.1991;6:37-40.

28. Deitch EA. Simple intestinal obstruction causes bacterial translocation in man. Arch Surg. 1989 Jun;124(6):699-701. PMID: 2730322.

29. Akçay MN, Capan MY, Gündogdu C, Polat M, Oren D. Bacterial translocation in experimental intestinal obstruction. J Int Med Res. 1996 Jan-Feb;24(1):17-26. PMID: 8674796.

30. Barbuto RC, Duval-Araujo I, Barral SM, Rocha RG, Bechara CS, Barbosa AJ. Use of alloplastic meshes in abdominal wounds of rats with induced peritonitis. Arq Bras Cir Dig. 2014 Jan-Mar;27(1):26-9. PMID: 24676294. 
Varella PZ et al.

31. Pundek MRZ, Czeczko NG, Yamamoto CT, Pizzatto RF, Czeczko LEA, Dietz UA, Malafaia O. Estudo das telas cirúrgicas de polipropileno/poliglecaprone e de polipropileno/polidioxanona/ celulose oxidada regenerada na cicatrização de defeito produzido na parede abdominal de ratos. ABCD Arq Bras Cir Dig. 2010;23(2):9499. doi: 10.1590/S0102-67202010000200007.

32. Utrabo CA, Czeczko NG, Busato CR, Montemor-Netto MR, Malafaia O, Dietz UA. Comparative study between polypropylene and polypropylene/poliglecaprone meshes used in the correction of abdominal wall defect in rats. Acta Cir Bras. 2012 Apr;27(4):300-5. PMID: 22534804.

\section{Correspondence:}

Paola Zarur Varella

Instituto de Pesquisas Médicas

Alameda Augustpo Stellfeld, 1980

80730-150 Curitiba - PR Brasil

Tel.: (55 41)3240-5488

paolazmed@yahoo.com.br

Received: Jun 20, 2016

Review: Aug 22, 2016

Accepted: Sep 21, 2016

Conflict of interest: none

Financial source: none

${ }^{1}$ Research performed at Medical Research Institute (IPEM), Postgraduate Program in Principles of Surgery, Faculdade Evangélica do Paraná (FEPAR), Curitiba-PR, Brazil. Part of Master degree thesis, Postgraduate Program in Principles of Surgery. Tutor: Nicolau Gregori Czeczko. 